Historic, archived document

Do not assume content reflects current scientific knowledge, policies, or practices. 



\section{$1=7640$}

United States

Department of

Agriculture

Forest Service

Intermountain

Research Station

Research Paper

INT-383

诸空
Occurrence of Conifer Seedlings and Their Microenvironments on Disturbed Sites in Central Idaho

Kathleen Geier-Hayes 


\section{THE AUTHOR}

KATHLEEN GEIER-HAYES is a forester in the Douglas-fir and Ponderosa Pine Ecosystems research work unit located at Intermountain Station's Forestry Sciences Laboratory in Boise, ID. She has worked part-time in this work unit since 1979 and joined the Intermountain Station on a full-time basis in 1986. She earned a B.S. degree in biology at Boise State University and an M.S. degree in forest science at the University of Idaho.

\section{RESEARCH SUMMARY}

Natural regeneration of six conifer species was surveyed on three central Idaho habitat types (h.t.): Douglas-fir/white spirea h.t. (Pseudotsuga menziesii/Spiraea betulifolia h.t.), grand fir/mountain maple h.t. (Abies grandis/Acer glabrum h.t.), and grand fir/blue huckleberry h.t. (Abies grandis/ Vaccinium globulare h.t.). The species sampled were lodgepole pine (Pinus contorta), western larch (Larix occidentalis), ponderosa pine (Pinus ponderosa), Douglas-fir (Pseudotsuga menziesii), Engelmann spruce (Picea engelmannii), and grand fir (Abies grandis). Seedling occurrence was related to seedbed, amount and kind of shade cover, site preparation method (no site preparation, broadcast burning, light and heavy scarification), and silvicultural method (clearcutting, seed-tree cutting, shelterwood cutting, selection cutting). An "index of regeneration efficiency" was developed to indicate possible beneficial and detrimental effects of seedbeds or covers for each seedling species. The indexes and percentage occurrences of seedlings are used to provide recommendations for silvicultural and site preparation treatments that can be used to obtain desired natural regeneration in the three habitat types. 


\title{
Occurrence of Conifer Seedlings and Their Microenvironments on Disturbed Sites in Central Idaho
}

\author{
Kathleen Geier-Hayes
}

\section{INTRODUCTION}

Successful forest management requires prompt tree regeneration following timber harvesting. With the increase in planting costs, many forest managers have turned to natural regeneration to restock stands (Gashwiler 1970). Natural regeneration of stands to adequate stocking levels is often slow (Fiedler and others 1985; Minore and Dubrasich 1981), and many studies have investigated the seedbed requirements for various conifer species. Few studies, however, have characterized the seedling microenvironment in terms of both seedbed and seedbed cover.

Seed germination and establishment depends on critical environmental conditions. A microenvironment that provides a seed with the requirements for germination and establishment was defined by Harper (1977) as a "safe site." The absence of a particular species from an area may be due either to insufficient seed dispersed to the site or to a lack of safe sites. Silviculturists use several methods to manipulate the amount of available conifer seed, but little is known about the required safe sites for that seed. Once identified, site preparations after timber harvesting can be manipulated to provide as many safe sites as possible for a desired conifer species. This study was undertaken to define safe sites for coniferous trees in west central Idaho.

\section{METHODS}

The study was conducted in the Douglas-fir (Pseudotsuga menziesii var. glauca) and grand fir (Abies grandis) forests on the Boise and Payette National Forests in west-central Idaho. In the Douglas-fir forests, Douglas-fir is the dominant species often growing with ponderosa pine (Pinus ponderosa) (Steele and others 1981). Grand fir is the dominant conifer in grand fir forests, often growing with ponderosa pine, lodgepole pine (Pinus contorta), Douglas-fir, Engelmann spruce (Picea engelmannii), and western larch (Larix occidentalis). Within these forests, three habitat types based on potential climax vegetation were sampled: Douglas-fir/white spirea (Pseudotsuga menziesii/Spiraea betulifolia) habitat type (h.t.), grand fir/mountain maple (Abies grandis/Acer glabrum) h.t., and grand fir/blue huckleberry (Abies grandis/Vaccinium globulare) h.t. (Steele and others 1981). The Douglas-fir habitat types are normally drier and warmer than the grand fir habitat types. The grand fir/mountain maple h.t. occurs in environments in the grand fir zone that are warmer than the grand fir/blue huckleberry h.t. environment.
Sample sites were located in the study area "subjectively but without preconceived bias" as described by Mueller-Dombois and Ellenberg (1974). Areas identified as Douglas-fir/white spirea, grand fir/mountain maple, and grand fir/blue huckleberry h.t. were reconnoitered to identify stands with some type of disturbance. Sample points were selected to represent the range of silvicultural methods and site preparation combinations available. The sample points were in representative portions of the stands in areas with uniform treatments. The silvicultural methods sampled included clearcuts, shelterwood cuts, seed-tree cuts, and group selection cuts. Site preparations included none (no slash disposal and little harvesting impact), broadcast burning, and two types of scarificationlight scarification (from slash disposal or harvesting activities) and heavy scarification (contour terracing). Only sites with 5-year-old or older disturbances were included. At each sampling point, five $108-\mathrm{ft}^{2}\left(10-\mathrm{m}^{2}\right)$ circular plots were located with one at the center (designated CENTER) and four peripheral (designated LEFT, RIGHT, UP, DOWN) $22.5 \mathrm{ft}(6.9 \mathrm{~m}$ ) from the middle of plot CENTER. Plots UP and DOWN were perpendicular to the contour upslope and downslope of CENTER respectively. Plots RIGHT and LEFT were on the contour to the right and left of CENTER. In using this sampling method, I assumed that safe sites were randomly dispersed within the uniform site treatment. All plots will be referred to as seedling plots. I treated each seedling plot as a separate plot for summarization.

For each seedling plot, I recorded the percentage of the plot covered by various soil surface conditions (seedbeds) and percentage coverages of vegetation and debris. Information on all conifer seedlings present included species, seedbed, and species of or kind of overhanging (influential) vegetation or debris. Seedbed categories were littercovered mineral soil, bare mineral soil, moss mats, residual duff, and rotten wood. Rocks and stumps were also recorded as seedbeds.

Seedlings 3 years old or older, but younger than the disturbance, were recorded. Seedlings were clipped and aged in the laboratory, or when possible, were aged on site by counting bud scars or nodes. Each individual seedling or cluster of seedlings (cache) was recorded as an occurrence. For each sample site I recorded aspect, slope, and elevation. The dates (year) of timber harvesting and site disturbance were estimated from management records, plantation signs, tree growth release indications from increment borings, and cross sections of machine scars that occurred during timber harvesting. All sampling 
occurred during the summers of 1984 and 1985. A total of 56 sites (280 seedling plots) were sampled in the Douglasfir/white spirea h.t.. 70 sites ( 350 seedling plots) in the grand fir/mountain maple h.t., and 24 sites (120 seedling plots) in the grand fir/blue huckleberry h.t.

The data from this study were not well suited to statistical analysis because the number of seedlings sampled of each species inadequately represented all the various silvicultural method-site preparation combinations, and the distribution of sampling plots throughout the combinations was not uniform. Rather, this was intended as a retrospective study of the effects of the rarious treatment combinations on the occurrence of natural tree regeneration.

I summarized the data by harvest-regeneration treatments, site preparation treatments, and amount of shade cover. For these summaries, the results are expressed as percentages based on the average number of seedlings for each treatment. Averages resulted from dividing the number of seedlings in a treatment by the number of treatments. Average number of years to establishment after disturbance rere obtained by subtracting the seedling age from the disturbance age and averaging the results for each species in a habitat type. The average is a weighted arrerage based on the number of seedlings of each species.

To evaluate the effect of the safe site components (seedbed or cover), an "index of regeneration efficiency" (RE) was calculated. The RE values were obtained by dividing the percentage occurrence of seedlings in a safe site component by the percentage occurrence of the safe site component. Percentage occurrence of seedlings is the percentage of seedlings that were found on or under a safe site component based on the total number of seedlings. Percentage occurrence of a safe site component was obtained by multiplying constancy of the safe site component (percentage occurrence over all plots) by average corer of each component. The ralues were totaled for all covers or seedbeds, and the totals were used to obtain percentage occurrence of a particular safe site component. The percentage occurrence of seedlings used to obtain $R E$ values is not the same as the percentages used for the previous summaries. This is because average number of seedlings per safe site component could not be obtained since the area occupied by each component varied from plot to plot. For this reason, RE values were used for these summaries. A regeneration efficiency of 1.00 indicates that the seedlings occurred in a particular safe site component in proportion to the occurrence of the component. Indexes greater than 1.00 indicate that seedling occurrence was much higher on a particular component than the occurrence of the component, and indexes less than 1.00 indicate that seedling occurrence is much lower than the occurrence of the component. Using this index, possible beneficial or detrimental effects of the safe site can be indicated. The following subjective categories and classes were assigned to $R E$ values:

Class 1: 0 to 0.25 , very inefficient

Class 2: 0.26 to 0.75 , inefficient

Class 3: 0.76 to 1.50 , efficient

Class 4: 1.51 to 3.00 , moderately efficient

Class 5: 3.01 and greater, very efficient.

\section{RESULTS AND DISCUSSION}

Approximately 370 seedlings per acre (920 per ha) were found in the Douglas-fir/white spirea h.t. (table 1). Regeneration was greater in the grand fir forests with 480 seedlings per acre $(1,190$ per ha) in both grand fir/mountain maple and grand fir/lue huckleberry h.t. Of the seedlings in the Douglas-fir/white spirea h.t., 64 percent were Douglas-fir, while ponderosa pine made up 24 percent of the total. In the grand fir forests, grand fir accounted for 49 percent in the mountain maple h.t. and 50 percent in the blue huckleberry h.t. Douglas-fir was also common. The average number of years to establishment after disturbance varied by species and by habitat type (table 1). Overall, seedling establishment took longest in the cool grand fir/blue huckleberry h.t. and was shortest in the moderate grand fir/mountain maple h.t.

\section{Seedbeds}

The most common seedbed safe site component in all three habitat types was litter-covered mineral soil followed by bare mineral soil and moss mats (table 2). Rocks or stumps, rotten wood, and residual duff were less common. Residual duff was amassments of organic material that had accumulated under the predisturbance stand and had remained intact following the disturbance. Litter-corered scarified soils were mineral soils that had been exposed. during the disturbance and were accumulating litter. Moss mats were composed primarily of juniper haircap moss (Polytrichum juniperinum), which produces loose, erect stems and was usually found on scarified soils.

In many cases $R E$ values were very efficient or moderately efficient for seedlings on residual duff, rotten wood, or moss mats. The RE values were mostly inefficient and efficient for seedlings on litter-covered and bare mineral soil. In other areas, investigators have found that seedlings often occurred on seedbeds of rotten wood or duff. Knapp and Smith (1982), in the Medicine Bow Mountains of southeastern Wyoming, and Day (1964), in the Crowsnest Forest of southwest Alberta, found that Engelmann spruce seedlings occurred on rotten wood and moss mats in a larger proportion than would be expected from the area occupied by the seedbed ( $\mathrm{RE}$ value greater than 1.00). Day (1964) also found that "mineral soil with incorporated humus" and "fermented and humified humus" were very efficient seedbeds for Engelmann spruce. Harrey (1982) states that rotten mood and humus proride a more favorable seedbed than does mineral soil because mineral soil gains and loses nutrients rapidly, has low nutrient and moisture holding capacities, and changes temperature quickly, whereas humus and decayed wood gain and lose nutrients slowly, have high nutrient and water-holding capacity, and change temperature slowly. Soil organic matter such as humus and decayed wood also increase the ability of the soil to support mycorrhizae, particularly on dry slopes (Harvey and others 1976). 
Table 1-Average number of tree seedlings per acre, percentage occurrence per acre, and average number of years to establishment after disturbance for tree seedlings in the Douglas-fir/white spirea, grand fir/mountain maple, and grand fir/blue huckleberry habitat types

\begin{tabular}{|c|c|c|c|c|}
\hline $\begin{array}{c}\text { Tree } \\
\text { species }\end{array}$ & $\begin{array}{c}\text { Average number } \\
\text { of seedlings } \\
\text { per acre }\end{array}$ & $\begin{array}{l}\text { Percent of } \\
\text { total sample }\end{array}$ & $\begin{array}{l}\text { Average number } \\
\text { of years to } \\
\text { establishment } \\
\text { after disturbance }\end{array}$ & $\begin{array}{l}\text { Range of years } \\
\text { to establishment }\end{array}$ \\
\hline \multicolumn{5}{|c|}{ Douglas-fir/White Spirea Habitat Type } \\
\hline Lodgepole pine & 44 & 12 & 3 & ${ }^{1} 0-14$ \\
\hline Ponderosa pine & 87 & 24 & 5 & $0-18$ \\
\hline Douglas-fir & 238 & 64 & 9 & $0-25$ \\
\hline Total & 369 & 100 & ${ }^{2} 7$ & \\
\hline \multicolumn{5}{|c|}{ Grand Fir/Mountain Maple Habitat Type } \\
\hline Lodgepole pine & 5 & 1 & 2 & $0-5$ \\
\hline Western larch & 21 & 4 & 1 & $0-14$ \\
\hline Ponderosa pine & 51 & 11 & 5 & $0-13$ \\
\hline Douglas-fir & 144 & 30 & 7 & $0-46$ \\
\hline Engelmann spruce & 25 & 5 & 3 & $0-6$ \\
\hline Grand fir & 234 & 49 & 7 & $0 \cdot 30$ \\
\hline Total & 480 & 100 & 6 & \\
\hline \multicolumn{5}{|c|}{ Grand Fir/Blue Huckleberry Habitat Type } \\
\hline Lodgepole pine & 29 & 6 & 9 & $2-20$ \\
\hline Ponderosa pine & 38 & 8 & 11 & $3-19$ \\
\hline Douglas-fir & 90 & 19 & 8 & $0-19$ \\
\hline Engelmann spruce & 81 & 17 & 7 & $0-22$ \\
\hline Grand fir & 237 & 50 & 9 & $0-29$ \\
\hline Total & 475 & 100 & 9 & \\
\hline
\end{tabular}

Table 2-Percentage occurrence of natural tree seedlings by seedbed with regeneration efficiencies (RE) ${ }^{1}$ classes of seedbeds for Douglas-fir/white spirea, grand fir/mountain maple, and grand fir/blue huckleberry habitat types

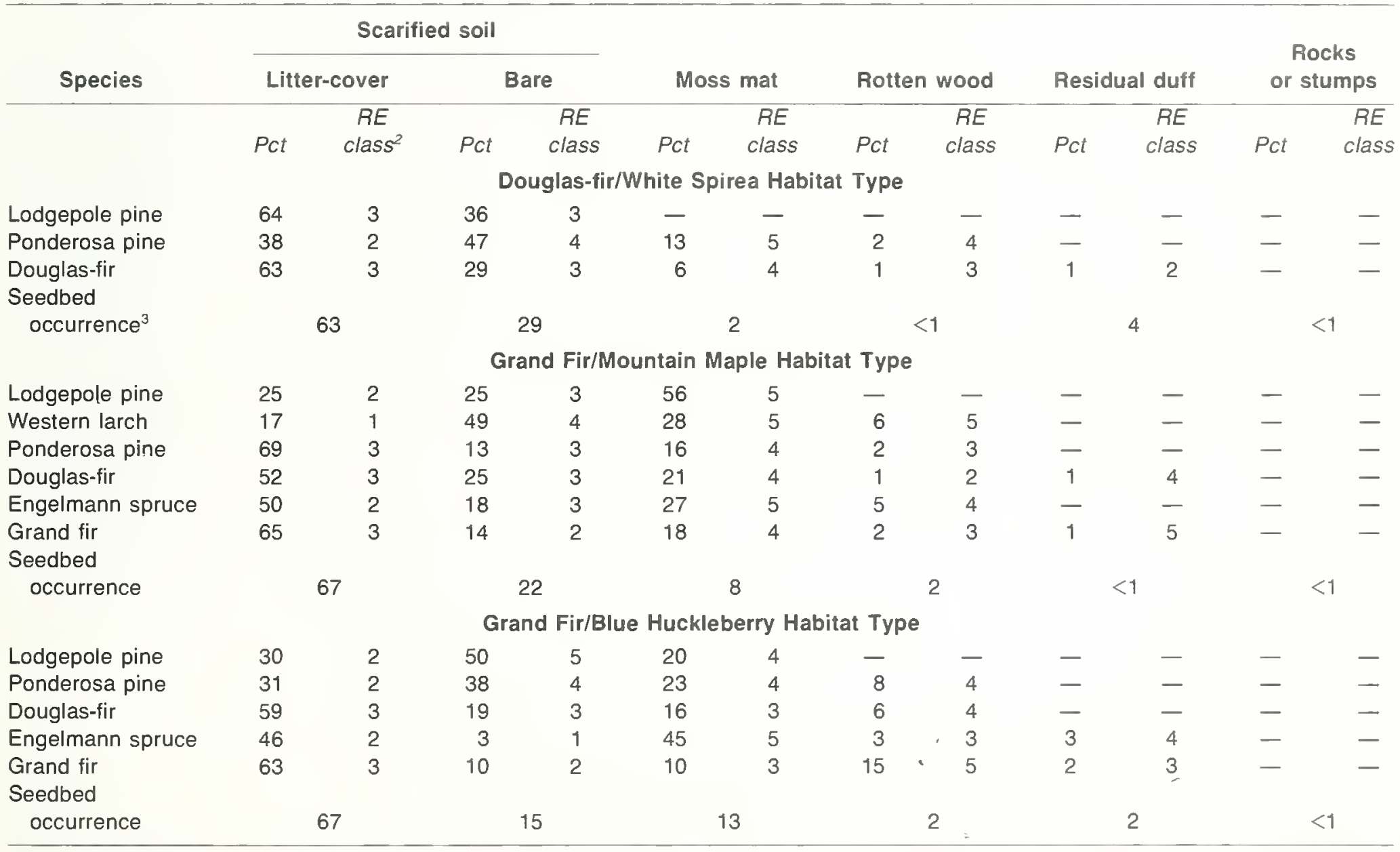

${ }^{1}$ Regeneration efficiency is the percentage occurrence of the seedling species divided by the percentage occurrence of the safe site component. ${ }^{2}$ Class 1: 0 to 0.25 , very inefficient; class $2: 0.26$ to 0.75 , inefficient; class $3: 0.76$ to 1.50 , efficient; class $4: 1.51$ to 3.00 , moderately efficient; class 5 : 3.01 and greater, very efficient.

${ }^{3}$ Seedbed occurrence is the percentage occurrence of a seedbed over all microplots. 


\section{Cover}

The second component of safe sites is the influence of vegetation and debris. The occurrence of different seedling species varied according to the amount of shrub canopy cover (shade) over the seedling plot (table 3). However, the trends for most species were similar between habitat types. Most seedling species occurred in moderate (33 to 66 percent shrub canopy cover) and heavy (67 to 100 percent) shade. This included even the shade-intolerant species ponderosa pine and lodgepole pine (as defined by Daniel and others 1979; Minore 1979), which were found predominately in moderate shade in all three habitat types. Douglas-fir was found most often under heavy shade. Engelmann spruce, which is rated as less shade tolerant than Douglas-fir (Minore 1979), was found most often under heavy shade in grand fir/mountain maple h.t. and under light ( 0 to 33 percent) shade in the grand fir/blue huckleberry h.t.

Table 3-Occurrence of tree seedlings (percentage) by shrub canopy cover for Douglas-fir/white spirea, grand $\mathrm{fir} / \mathrm{mountain}$ maple, and grand fir/blue huckleberry habitat types

\begin{tabular}{|c|c|c|c|}
\hline \multirow[b]{2}{*}{$\begin{array}{l}\text { Occurrence by } \\
\text { species }\end{array}$} & \multicolumn{3}{|c|}{ Shrub canopy cover } \\
\hline & $\begin{array}{l}\text { Light } \\
(0-33 \%)\end{array}$ & $\begin{array}{l}\text { Moderate } \\
(33-66 \%)\end{array}$ & $\begin{array}{c}\text { Heavy } \\
(66-100 \%)\end{array}$ \\
\hline \multicolumn{4}{|c|}{ Douglas-fir/White Spirea Habitat Type } \\
\hline $\begin{array}{l}\text { Percentage of } \\
\text { microplots }\end{array}$ & 42 & 36 & 22 \\
\hline Lodgepole pine & 16 & 44 & 40 \\
\hline Ponderosa pine & 17 & 42 & 41 \\
\hline Douglas-fir & 31 & 32 & 37 \\
\hline \multicolumn{4}{|c|}{ Grand Fir/Mountain Maple Habitat Type } \\
\hline Number of microplots & 34 & 26 & 40 \\
\hline Lodgepole pine & 20 & 80 & - \\
\hline Western larch & 34 & 58 & 8 \\
\hline Ponderosa pine & 27 & 49 & 24 \\
\hline Douglas-fir & 23 & 14 & 63 \\
\hline Engelmann spruce & 15 & 20 & 65 \\
\hline Grand fir & 32 & 38 & 30 \\
\hline \multicolumn{4}{|c|}{ Grand Fir/Blue Huckleberry Habitat Type } \\
\hline Number of microplots & 28 & 35 & 37 \\
\hline Lodgepole pine & 12 & 60 & 28 \\
\hline Ponderosa pine & 28 & 45 & 27 \\
\hline Douglas-fir & 35 & 22 & 43 \\
\hline Engelmann spruce & 46 & 17 & 37 \\
\hline Grand fir & 26 & 25 & 49 \\
\hline
\end{tabular}

While the large occurrence of shade-tolerant species on moderately or heavily shaded plots would be expected, the high occurrence of shade-intolerant species on such plots appears incongruent. McConkie and Mowat (1936) found that germination of ponderosa pine in central Idaho was higher under heavy shade, though the death rate of the first-year germinants was also higher under heavy shade than under more intermediate shade or no shade. The net effect at the end of the year was an increase in seedling occurrence with increasing shade. This relationship may hold for many years. The presence of a shade-intolerant species under heavy shade may indicate a safe site-that is, a favorable microenvironment for germination and establishment. However, other safe sites such as a safe site with light shade may provide for faster seedling growth.

Several safe site covers were encountered for the various seedlings throughout the three habitat types (table 4). While the cover RE values often varied considerably between habitat types for the same conifer seedling species, in some cases the $R E$ values for cover species were consistently high or low across habitat types. Notably, thimbleberry (Rubus parviflorus) was very efficient for lodgepole pine, ponderosa pine, Douglas-fir, Engelmann spruce, and grand fir in the grand fir/blue huckleberry h.t. and for ponderosa pine and Engelmann spruce in the grand fir/mountain maple h.t. Cover of forbs and grasses and sedges was consistently either very inefficient or inefficient for all species in all three habitat types. The use of a "cover species" and the associated $\mathrm{RE}$ value does not intend to imply that a particular cover precludes or is required to obtain a particular seedling. In many cases, the relationship between the cover species and the seedling species may be coincidental; the seedling and the cover species may merely have established in the same location at the same time. On the other hand, a very high or very low $R E$ value may indicate a relationship. The particular cover species may be established in a microenvironment that is favorable or unfavorable to a particular conifer species, and therefore can be used as an indicator of a suitable or unsuitable microenvironment. An example of such a species is Sitka alder (Alnus sinuata), which is a very efficient cover species for Engelmann spruce in the grand fir/mountain maple h.t. Sitka alder often occurs in wetter portions of the grand fir/mountain maple h.t., indicating areas that are well suited to Engelmann spruce (Steele and Geier-Hayes 1985). Other cover species may by their characteristics affect the safe site. On one hand, an allelopathic species may preclude the formation of a safe site. On the other hand, a species that supports nitrogenfixing organisms may create a safe site by providing a favorable rooting environment. 
Table 4-Regeneration efficiency (RE) ${ }^{1}$ classes for shrub canopies and other microsites for Douglas-fir/white spirea, grand fir/mountain maple, and grand fir/blue huckleberry habitat types

\begin{tabular}{|c|c|c|c|c|c|c|c|c|}
\hline \multirow[b]{2}{*}{ Type of cover } & \multirow[b]{2}{*}{ Constancy } & \multirow[b]{2}{*}{$\begin{array}{c}\text { Area } \\
\text { occupied }\end{array}$} & \multicolumn{6}{|c|}{ Species } \\
\hline & & & $\begin{array}{l}\text { Lodgepole } \\
\text { pine }\end{array}$ & $\begin{array}{l}\text { Western } \\
\text { larch }\end{array}$ & $\begin{array}{l}\text { Ponderosa } \\
\text { pine }\end{array}$ & Douglas-fir & $\begin{array}{l}\text { Engelmann } \\
\text { spruce }\end{array}$ & $\begin{array}{c}\text { Grand } \\
\text { fir }\end{array}$ \\
\hline
\end{tabular}

None

Grasses and sedges

Forbs

Spiraea betulifolia

Pinus ponderosa

Prunus spp.

Slash

Symphoricarpos spp.

Amelanchier alnifolia

Berberis repens

Ribes spp.

Populus tremuloides

Ceanothus velutinus

Salix scouleriana

Pseudotsuga menziesii

Purshia tridentata

Pinus contorta

Artemisia tridentata

Rosa spp.

Rubus parviflorus

Lonicera utahensis

Sorbus scopulina

Acer glabrum

Physocarpus malvaceus

Sambucus racemosa

None

Forbs

Rubus parviflorus

Ceanothus velutinus

Grasses and sedges

Salix scouleriana

Slash

Pinus ponderosa

Ribes spp.

Vaccinium globulare

Physocarpus malvaceus

Abies grandis

Alnus sinuata

Lonicera utahensis

Acer glabrum

Spiraea betulifolia

Pseudotsuga menziesii

Prunus spp.

Symphoricarpos spp.

Pachistima myrsinites

Sorbus scopulina

Amelanchier alnifolia

Rosa spp.

Larix occidentalis

Shepherdia canadensis

Picea engelmannii

Populus tremuloides

Artemisia tridentata

Clematis columbiana

Sambucus racemosa

Berberis repens
Douglas-fir/White Spirea Habitat Type

$\begin{array}{cccc}{ }^{2} 68 & - & 41 & 5 \\ - & - & 3_{1} & 1 \\ - & - & - & 2 \\ 4 & - & 3 & 4 \\ - & - & 3 & 3 \\ - & - & - & 1 \\ - & - & 3 & 4 \\ - & - & 3 & 2 \\ - & - & 3 & 3 \\ - & - & - & 2 \\ - & - & - & 2 \\ - & - & - & 2 \\ - & - & 4 & 4 \\ - & - & 3 & 3 \\ - & - & 3 & - \\ - & - & 4 & 4 \\ 5 & - & - & 3 \\ - & - & 5 & - \\ - & - & - & - \\ - & - & - & - \\ - & - & - & - \\ - & - & - & - \\ - & - & - & - \\ - & - & - & -\end{array}$

Grand Fir/Mountain Maple Habitat Type

$\begin{array}{llll}25 & 24 & 27 & 14\end{array}$

$\begin{array}{llll}- & - & 1 & 2\end{array}$

- 3

- 2

- -

- $\quad-$

- $\quad-$

- 5

- 5

$-$

5

$-$

$5 \quad 5$

$\begin{array}{llll}- & - & - & 4\end{array}$

$\begin{array}{llll}- & - & - & -\end{array}$

$\begin{array}{llll}- & - & - & 2\end{array}$

$\begin{array}{llll}- & - & - & 3\end{array}$

$\begin{array}{llll}- & - & - & 3 \\ - & - & - & 4\end{array}$

- $\quad-$

$-\quad-$

$\overline{-} \quad-$

$-$

$-$

$-$

$\overline{-}$

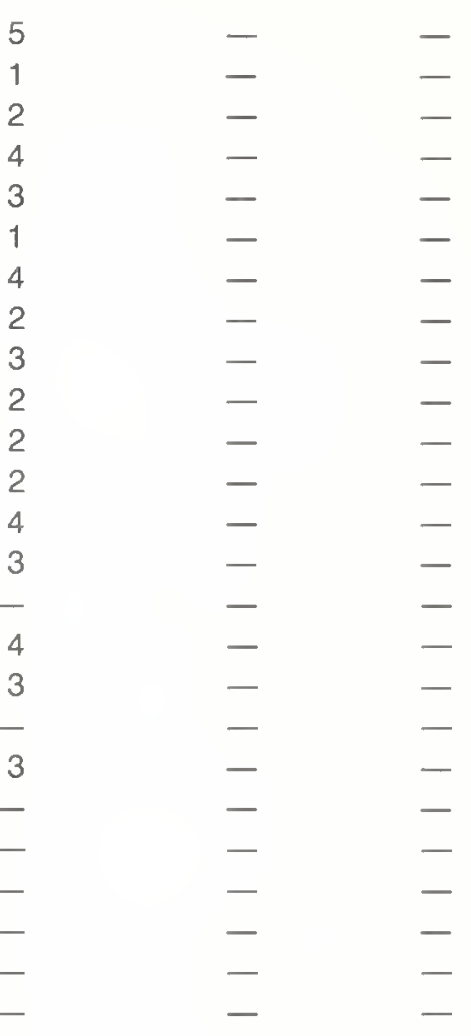

\begin{tabular}{|c|c|}
\hline 18 & 19 \\
\hline 2 & 2 \\
\hline 5 & 2 \\
\hline- & 3 \\
\hline- & 1 \\
\hline 2 & 3 \\
\hline 2 & 2 \\
\hline- & 2 \\
\hline- & 3 \\
\hline 3 & 4 \\
\hline 4 & 4 \\
\hline- & 2 \\
\hline 5 & 2 \\
\hline- & 3 \\
\hline- & 5 \\
\hline- & 2 \\
\hline- & 3 \\
\hline- & 2 \\
\hline- & - \\
\hline- & - \\
\hline 5 & - \\
\hline- & - \\
\hline- & - \\
\hline- & - \\
\hline- & 5 \\
\hline- & - \\
\hline- & - \\
\hline- & - \\
\hline- & - \\
\hline- & - \\
\hline- & - \\
\hline
\end{tabular}

(con.) 


\section{Species}

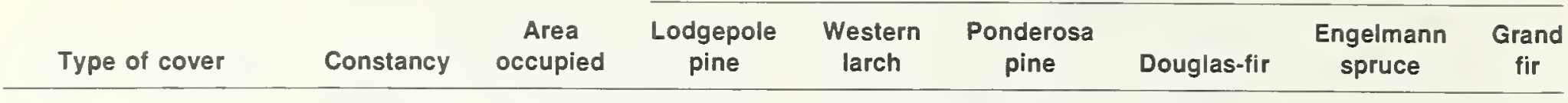

\section{None}

Grasses

Forbs

Vaccinium globulare

Pinus ponderosa

Salix scouleriana

Lonicera utahensis

Alnus sinuata

Ceanothus velutinus

Ribes spp.

Abies grandis

Slash

Spiraea betulifolia

Pinus contorta

Larix occidentalis

Shepherdia canadensis

Pseudotsuga menziesii

Rubus parviflorus

Sambucus racemosa

Pachistima myrsinites

Picea engelmannii

Rosa spp.

Symphoricarpos

oreophilus

Amelanchier alnifolia

Physocarpus malvaceus

Sorbus scopulina

Prunus spp.

\section{Grand Fir/Blue Huckleberry Habitat Type}

\begin{tabular}{|c|c|c|c|c|c|}
\hline 10 & - & 31 & 13 & 11 & 7 \\
\hline- & - & 2 & - & - & 1 \\
\hline- & - & - & 2 & 2 & 1 \\
\hline 4 & - & 4 & 4 & 4 & 4 \\
\hline- & - & - & 2 & 2 & 4 \\
\hline- & - & - & 3 & 4 & 4 \\
\hline 5 & - & - & 2 & 4 & 1 \\
\hline - & - & - & - & - & 2 \\
\hline- & - & - & 2 & - & 3 \\
\hline- & - & 4 & 3 & 2 & 3 \\
\hline- & - & - & - & - & - \\
\hline- & - & - & - & - & 4 \\
\hline 5 & - & - & 4 & 3 & 3 \\
\hline- & - & - & - & - & - \\
\hline- & - & - & - & - & - \\
\hline- & - & - & - & - & - \\
\hline- & - & - & - & - & - \\
\hline 5 & - & 5 & 5 & 5 & 5 \\
\hline- & - & - & - & - & - \\
\hline- & - & - & 5 & - & - \\
\hline- & - & - & - & 5 & - \\
\hline- & - & - & - & - & - \\
\hline- & - & - & $\dot{-}$ & - & - \\
\hline- & - & 5 & - & - & - \\
\hline- & - & - & - & - & - \\
\hline- & - & - & - & - & - \\
\hline- & - & - & - & - & - \\
\hline
\end{tabular}

${ }^{1}$ Regeneration efficiency is the percentage occurrence of the seedling species divided by the percentage occurrence of the safe site component.

2During sampling, no estimate of "none" type of cover was made for each plot. Therefore, this value is the percentage of seedlings that had no cover. The remaining percentage is represented in the RE value for the type of cover under which the seedling was found.

${ }^{3}$ Class 1: 0 to 0.25 , very efficient; class $2: 0.26$ to 0.75 , inefficient; class $3: 0.76$ to 1.50 , efficient; class $4: 1.51$ to 3.00 , moderately efficient; class $5: 3.01$ and greater, very efficient. 


\section{Site Treatment}

The cover species and seedbeds that remain on the site after timber harvesting are influenced by the type of site preparation used to dispose of slash or prepare for artificial regeneration. For most species in most habitat types, scarification resulted in the largest proportion of seedlings (table 5). Moss mats, which were moderately efficient or very efficient seedbeds for most species, usually occurred on sites that had been scarified and occasionally on sites that had been broadcast burned. Broadcast burning resulted in the largest proportion of Douglas-fir seedlings in both the Douglas-fir/white spirea and grand fir/blue huckleberry h.t.

Table 5-Occurrence of tree seedlings (percentage) by site preparation methods for Douglas-fir/white spirea, grand fir/mountain maple, and grand fir/blue huckleberry habitat types

\begin{tabular}{|c|c|c|c|c|}
\hline \multirow[b]{2}{*}{ Species } & \multirow{2}{*}{$\begin{array}{c}\text { No } \\
\text { preparation }\end{array}$} & \multirow{2}{*}{$\begin{array}{l}\text { Broadcast } \\
\text { burn }\end{array}$} & \multicolumn{2}{|c|}{ Scarification } \\
\hline & & & Light & Heavy \\
\hline \multicolumn{5}{|c|}{ Douglas-fir/White Spirea Habitat Type } \\
\hline $\begin{array}{l}\text { Percentage of } \\
\text { microplots }\end{array}$ & 6 & 15 & 50 & 29 \\
\hline Lodgepole pine & - & 41 & 59 & - \\
\hline Ponderosa pine & 19 & 22 & 44 & 15 \\
\hline Douglas-fir & 8 & 58 & 27 & 7 \\
\hline \multicolumn{5}{|c|}{ Grand Fir/Mountain Maple Habitat Type } \\
\hline Number of microplots & 15 & 7 & 55 & 23 \\
\hline Lodgepole pine & - & - & 100 & - \\
\hline Western larch & - & - & 87 & 13 \\
\hline Ponderosa pine & 29 & 14 & 12 & 45 \\
\hline Douglas-fir & 24 & 4 & 35 & 37 \\
\hline Engelmann spruce & - & - & 80 & 20 \\
\hline Grand fir & 17 & 27 & 33 & 23 \\
\hline \multicolumn{5}{|c|}{ Grand Fir/Blue Huckleberry Habitat Type } \\
\hline Number of microplots & 4 & 11 & 64 & 21 \\
\hline Lodgepole pine & - & 29 & 42 & 29 \\
\hline Ponderosa pine & - & - & 80 & 20 \\
\hline Douglas-fir & - & 39 & 36 & 25 \\
\hline Engelmann spruce & - & - & 67 & 33 \\
\hline Grand fir & - & 38 & 24 & 38 \\
\hline
\end{tabular}

\section{Silvicultural Methods}

Silvicultural activities influence the safe site both by altering the availability of site protection and by influencing the dispersal of seed to the safe site. In the Douglasfir/white spirea h.t., the largest proportion of lodgepole pine and ponderosa pine seedlings was found under shelterwood cuts (table 6). As would be expected, seedlings occurred predominately in cutting units with a seed source for the particular species present within or close to the cutting unit. In the grand fir/mountain maple h.t., only Engelmann spruce and grand fir were most common in shelterwoods. Western larch and Douglas-fir occurred predominately in seed-tree cutting units. In the grand fir/blue huckleberry h.t., lodgepole pine and Engelmann spruce were most common in shelterwood cuts, while ponderosa pine, Douglas-fir, and grand fir were predominate in clearcuts.

\section{Species}

Lodgepole Pine-Lodgepole pine regenerated best under shelterwood cuts in the Douglas-fir/white spirea and grand fir/blue huckleberry h.t. and best under seed-tree cuts in the grand fir/mountain maple h.t. Lodgepole pine is mostly nonserotinous in central Idaho (Steele and others 1981), and the high incidence of lodgepole pine seedlings under the shelterwood was probably because of an adequate seed source rather than the environmental conditions provided by the residual overstory. In south-central Oregon, Dahms (1963) found that 85 percent of the seed dispersed into clearcuts fell within $66 \mathrm{ft}(20 \mathrm{~m})$ of the seed source. Boe (1956) reported that in central Montana, 84 percent of the seed fell within $198 \mathrm{ft}(60 \mathrm{~m})$ of the seed source. Dahms (1963) recommends that clearcutting units should not be larger than $400 \mathrm{ft}(122 \mathrm{~m})$ across. Trappe (1959) suggests using long, narrow clearcuts or seed-tree cuts with seed-trees placed not more than $198 \mathrm{ft}(60 \mathrm{~m})$ apart.

For all three habitat types, most seedlings occurred on sites with light scarification. Trappe (1959), Boe (1956), Day and Duffy (1963), and Roe (1952) also found that lodgepole pine occurred most often on scarified sites on mineral soil. In central Idaho, mineral soil or moss mats were efficient, moderately efficient, or very efficient seedbeds. Most seedlings occurred in moderate shade in all three habitat types. Several covers were moderately efficient or very efficient for lodgepole pine including Utah honeysuckle (Lonicera utahensis), thimbleberry, blue huckleberry, and white spirea.

Western Larch-Western larch seedlings occurred exclusively in the grand fir/mountain maple h.t. Most seedlings were found under seed-tree cuts with a western larch overstory, particularly on sites with scarification. Boe (1953) found that western larch in northwestern Montana dispersed seed up to $396 \mathrm{ft}(121 \mathrm{~m})$. Shearer (1959), also working in northwestern Montana, reported that virtually all seed that disseminated farther than $264 \mathrm{ft}(80 \mathrm{~m})$ were released during good seed years and that the smaller the seed crop, the shorter the average dispersal distance. Shearer also indicated that most of the seed was disseminated by thermal slope winds generated by warm, dry weather rather than by prevailing winds. Boyd (1969) found in northern Idaho that clearcuts ranging from 264 to $462 \mathrm{ft}$ wide ( 80 to $141 \mathrm{~m}$ ) produced more seedlings than seed-tree cuts or shelterwood cuts. Mineral soils were the most common seedbeds in other areas (Boyd and Deitschman 1969; Roe 1952). However, in central Idaho, moss mats and rotten wood were very efficient seedbeds. Even though Roe (1952) found more western larch seedlings in light shade, most seedlings in central Idaho were found in moderate shade, particularly under blue huckleberry, currant (Ribes spp.), and Utah honeysuckle. 
Table 6-Occurrence of tree seedlings (percentage) by silvicultural method and overstory composition for Douglas-fir/white spirea, grand fir/mountain maple, and grand fir/blue huckleberry habitat types

\begin{tabular}{|c|c|c|c|c|c|c|c|c|}
\hline \multirow[b]{2}{*}{$\begin{array}{l}\text { Silvicultural } \\
\text { method }\end{array}$} & \multirow[b]{2}{*}{$\begin{array}{l}\text { Percent } \\
\text { cover }\end{array}$} & \multirow[b]{2}{*}{$\begin{array}{c}\text { Percentage } \\
\text { of sites }\end{array}$} & \multicolumn{6}{|c|}{ Species } \\
\hline & & & $\begin{array}{l}\text { Lodgepole } \\
\text { pine }\end{array}$ & $\begin{array}{l}\text { Western } \\
\text { larch }\end{array}$ & $\begin{array}{c}\text { Ponderosa } \\
\text { pine }\end{array}$ & Douglas-fir & $\begin{array}{c}\text { Engelmann } \\
\text { spruce }\end{array}$ & $\begin{array}{l}\text { Grand } \\
\text { fir }\end{array}$ \\
\hline & & \multicolumn{7}{|c|}{ Douglas-fir/White Spirea Habitat Type } \\
\hline Clearcut & & 58 & 20 & - & 22 & 28 & - & - \\
\hline \multirow[t]{2}{*}{ Seed-tree cut } & & 18 & 0 & - & 21 & 26 & - & - \\
\hline & & $\cdots$ & -... See & ing occurrer & (percent) wit & seed-tree cu & $\ldots \ldots$ & $\cdots$ \\
\hline Ponderosa pine & 7 & 67 & - & - & 100 & ${ }^{1} 45$ & - & - \\
\hline Ponderosa pine & 39 & 22 & - & - & - & 39 & - & - \\
\hline Douglas-fir & 5 & & & & & & & \\
\hline Douglas-fir & 15 & 11 & - & - & - & 16 & - & - \\
\hline \multirow[t]{2}{*}{ Shelterwood cut } & & 10 & 80 & - & 45 & 26 & - & - \\
\hline & & $\ldots \ldots$ & ... Seed & g occurreno & (percent) with & shelterwood c & $\ldots . . .$. & $\ldots$. \\
\hline Lodgepole pine & 3 & 20 & 100 & & 16 & 70 & - & - \\
\hline Ponderosa pine & 15 & & & & & & & \\
\hline Douglas-fir & 6 & & & & & & & \\
\hline Ponderosa pine & 16 & 60 & - & - & 37 & ${ }^{1} 30$ & - & - \\
\hline Ponderosa pine & 20 & 20 & - & - & 47 & - & - & - \\
\hline Douglas-fir & 15 & & & & & & & \\
\hline \multirow[t]{2}{*}{ Selection cut } & & 14 & 0 & - & 12 & 20 & - & - \\
\hline & & $\ldots \ldots$ & . . . See & ing occurrer & (percent) wi & selection cut & $\ldots . .$. & $\cdots$ \\
\hline Lodgepole pine & 15 & 14 & - & & - & 11 & - & - \\
\hline Ponderosa pine & 3 & & & & & & & \\
\hline Douglas-fir & 18 & & & & & & & \\
\hline Ponderosa pine & 24 & 43 & - & - & - & 29 & - & - \\
\hline Douglas-fir & 8 & & & & & & & \\
\hline Ponderosa pine & 11 & 29 & - & - & 14 & 5 & - & - \\
\hline \multirow[t]{2}{*}{ Douglas-fir } & 15 & 14 & - & - & ${ }^{1} 86$ & 55 & - & - \\
\hline & & \multicolumn{7}{|c|}{ Grand Fir/Mountain Maple Habitat Type } \\
\hline Clearcut & & 66 & 5 & 9 & 12 & 22 & 30 & 20 \\
\hline \multirow[t]{2}{*}{ Seed-tree cut } & & 8 & 73 & 84 & 29 & 28 & 70 & 26 \\
\hline & & $\ldots \ldots$. & $\ldots .-S_{e}$ & lling occurre & $e$ (percent) $w$ & in seed-tree $c$ & ..... & -.. \\
\hline Western larch & 3 & 17 & - & 52 & - & - & - & - \\
\hline Western larch & 3 & 17 & 100 & 39 & - & - & 100 & 70 \\
\hline Engelmann spruce & 6 & & & & & & & \\
\hline Ponderosa pine & 3 & 49 & - & ${ }^{1} 9$ & 100 & ${ }^{1} 100$ & - & 23 \\
\hline Grand fir & 15 & 17 & - & - & - & - & - & 7 \\
\hline \multirow[t]{2}{*}{ Shelterwood cut } & & 11 & 0 & 7 & 0 & 32 & 0 & 44 \\
\hline & & $\ldots .$. & ... See & ing occurrer & (percent) wit & shelterwood & $\ldots . .$. & $\cdots$ \\
\hline Western larch & 3 & 13 & - & 100 & - & 56 & - & 18 \\
\hline Douglas-fir & 33 & & & & & & & \\
\hline Grand fir & 15 & & & & & & & \\
\hline Douglas-fir & 18 & 13 & - & - & - & - & - & 13 \\
\hline Douglas-fir & 13 & 61 & - & - & - & 10 & - & 5 \\
\hline Grand fir & 12 & & & & & & & \\
\hline Grand fir & 53 & 13 & - & - & - & ${ }^{1} 35$ & - & 64 \\
\hline Selection cut & & 14 & 22 & 0 & 59 & 18 & 0 & 10 \\
\hline
\end{tabular}

No cover

Lodgepole pine

Grand fir

Ponderosa pine

Douglas-fir

Grand fir

Ponderosa pine

Grand fir

Douglas-fir

Douglas-fir

Grand fir

Grand fir ....

\section{0}

10

10

20

10

10

30
- - Seedling occurrence (percent)

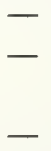

27

$-$

173

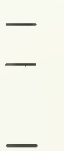

-

-

within selection

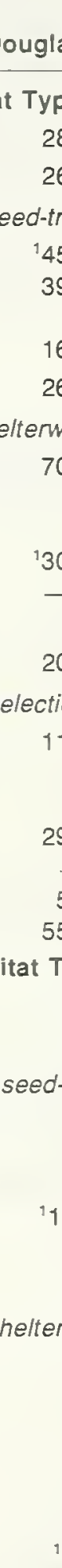

tion cuts - . - .

$-$ 13

64

10

-

(7)

- 


\begin{tabular}{|c|c|c|c|c|c|c|c|c|}
\hline \multirow[b]{2}{*}{$\begin{array}{l}\text { Silvicultural } \\
\text { method }\end{array}$} & \multirow[b]{2}{*}{$\begin{array}{l}\text { Percent } \\
\text { cover }\end{array}$} & \multirow[b]{2}{*}{$\begin{array}{c}\text { Percentage } \\
\text { of sites }\end{array}$} & \multicolumn{6}{|c|}{ Species } \\
\hline & & & $\begin{array}{l}\text { Lodgepole } \\
\text { pine }\end{array}$ & $\begin{array}{l}\text { Western } \\
\text { larch }\end{array}$ & $\begin{array}{c}\text { Ponderosa } \\
\text { pine }\end{array}$ & Douglas-fir & $\begin{array}{l}\text { Engelmann } \\
\text { spruce }\end{array}$ & $\begin{array}{c}\text { Grand } \\
\text { fir }\end{array}$ \\
\hline & & \multicolumn{7}{|c|}{ Grand Fir/Blue Huckleberry Habitat Type } \\
\hline Clearcut & & 82 & 26 & - & 100 & 56 & 24 & 53 \\
\hline \multirow[t]{2}{*}{ Seed-tree cut } & & 7 & 0 & - & 44 & 44 & 0 & 24 \\
\hline & & $\ldots \ldots \ldots$ & $\ldots$... Seed & g occurrer & (percent) wit & n seed-tree cl & $\ldots . . . . .$. & $\ldots$. \\
\hline Ponderosa pine & 15 & 50 & - & - & - & - & - & 100 \\
\hline Douglas-fir & 3 & & & & & & & \\
\hline Engelmann spruce & 3 & & & & & & & \\
\hline Douglas-fir & 3 & 50 & - & - & - & 100 & - & - \\
\hline Grand fir & 3 & & & & & & & \\
\hline \multirow[t]{2}{*}{ Shelterwood cut } & & 7 & 74 & - & 0 & 0 & 76 & 7 \\
\hline & & $\ldots \ldots . .$. & ... Seedli & occurrenc & (percent) with & shelterwood & $s \ldots . . .$. & $\ldots .$. \\
\hline Lodgepole pine & 1 & 50 & - & - & - & - & - & - \\
\hline Grand fir & 53 & & & & & & & \\
\hline Douglas-fir & 15 & 50 & 100 & - & - & - & 100 & 100 \\
\hline Engelmann spruce & 3 & & & & & & & \\
\hline Grand fir & 18 & & & & & & & \\
\hline \multirow[t]{2}{*}{ Selection cut } & & 4 & 0 & - & 0 & 0 & 0 & 16 \\
\hline & & $\ldots \ldots . .$. & $\ldots .$. Seed & hg occurrer & (percent) wit & n selection $\mathrm{cl}$ & $\ldots \ldots . .$. & $\ldots$. \\
\hline Engelmann spruce & 18 & 100 & - & - & - & - & - & 100 \\
\hline Grand fir & 45 & & & & & & & \\
\hline
\end{tabular}

1Seed source within 100 feet $(30 \mathrm{~m})$ of sample plot.

Ponderosa Pine-Ponderosa pine occurred most often in the warm, dry Douglas-fir/white spirea h.t. Here, ponderosa pine regeneration was highest under shelterwoods, while in both of the cooler, moister grand fir habitat types, regeneration was highest under selection cuts and on clearcuts. Ponderosa pine seed does not disseminate naturally over long distances; in central Oregon, most seed fell within $132 \mathrm{ft}$ ( $40 \mathrm{~m}$ ) of the seed source (Barrett 1966). Curtis and Foiles (1961) reported that in central Idaho, most ponderosa pine seed fell within $66 \mathrm{ft}(20 \mathrm{~m})$ of the seed source.

As with the lodgepole pine and western larch, scarification treatments produced the largest number of ponderosa pine seedlings. Tackle and Roy (1953), Roy (1983), and Shearer and Schmidt (1970) indicated that scarification treatments resulted in more seedlings than did other treatments. Foiles and Curtis (1965) reported that the seed-toseedling ratio was $55: 1$ on scarified areas, while the ratio was $6,150: 1$ on unscarified areas. In the Douglas-fir/white spirea and grand fir/blue huckleberry h.t., light scarification was best, while in the grand fir/mountain maple h.t., most seedlings occurred from heavy scarification. Moss mats, rotten wood, and bare soil were moderately efficient and very efficient seedbeds in the Douglas-fir/white spirea and the grand fir/blue huckleberry h.t. Most seedlings were found in moderate shade in all three habitat types. Big sagebrush (Artemisia tridentata), thimbleberry, rose (Rosa spp.), and serviceberry (Amelanchier alnifolia) were very efficient covers.

Not all of the incidences of ponderosa pine resulted from natural seedfall. In the Douglas-fir/white spirea h.t., 16 percent of the occurrences of ponderosa pine resulted from seed caches. In both the grand fir/mountain maple and grand fir/blue huckleberry h.t., 17 percent of the occurrences were in seed caches. In central Idaho, McConkie and Mowat (1936) found that 14 percent of the ponderosa pine occurrences were the result of seed caches. Saigo (1969) and West (1968), both working on the east side of the central Oregon Cascades, found that seedling caches occurred 21 and 15 percent, respectively.

Various animals have been implicated as the source of these seed caches. Giuntoli and Mewaldt (1978), in the Bitterroot Range in Montana, found that Clark's nutcracker (Nucifraga columbiana) ate and probably cached ponderosa pine seed in the same manner that limber pine (Pinus flexilis) and whitebark pine (P. albicaulis) are stored (Giuntoli and Mewaldt 1978; Lanner and Vander Wall 1980; Vander Wall and Balda 1977; Vander Wall and Hutchins 1983). Saigo (1969) indicated that most seed caches in her study area probably resulted from the golden-mantled ground squirrel (Spermophilus lateralis) or the yellow pine chipmunk (Eutamias amoenus). Both of these rodents are present in central Idaho. However, the yellow pine chipmunk was probably most common within the studied habitat types (Steele 1986). Other animals in the study areas, namely the Steller's jay (Cyanocitta stelleri) and deer mouse (Peromyscus maniculatus), also cache seed. However, these animals cache single seeds rather than groups of seed (Hofmann 1923; Lanner 1980). Seedlings that may have resulted from single seed caches could not be distinguished from seedlings that resulted from natural seedfall.

Douglas-fir-Douglas-fir occurrence was similar to the occurrence of ponderosa pine. It was highest in the Douglas-fir/white spirea h.t. and lowest in the grand fir/ blue huckleberry h.t. Douglas-fir seedlings were found in 
almost equal amounts under different silvicultural treatments in the Douglas-fir/white spirea h.t., though occurrence in clearcuts was slightly higher than occurrences under other treatments. However, in the grand fir/blue huckleberry h.t., more than half of the Douglas-fir seedlings were found in clearcuts. In grand fir/mountain maple, more seedlings were found under shelterwoods. In northwestern Montana, Douglas-fir seed dispersed up to $264 \mathrm{ft}(80 \mathrm{~m}$ ) (Boe 1953). Boyd (1969) found that most seedlings occurred in clearcuts in northern Idaho though slightly fewer were found in shelterwood cuts, while Day and Duffy (1963), working in Canada, recommend shelterwood cutting.

Scarification treatments favored Douglas-fir seedlings in both grand fir habitat types. However, broadcast burning was most beneficial in the Douglas-fir/white spirea h.t. Moderately efficient seedbeds were moss mats in Douglasfir/white spirea and grand fir/mountain maple h.t., residual duff in grand fir/mountain maple h.t., and rotten wood in grand fir/blue huckleberry h.t. Roe (1952) found most seedlings on mineral soil, but Day and Duffy (1963) reported that moss mats and decayed wood were better seedbeds than mineral soil. In the Douglas-fir/white spirea h.t., white spirea, ceanothus (Ceanothus velutinus), slash, and bitterbrush (Purshia tridentata) were moderately efficient cover. Blue huckleberry, mountain maple, and pachistima (Pachistima myrsinites) were moderately efficient in grand fir/mountain maple h.t., and thimbleberry and pachistima were very efficient in grand fir/blue huckleberry h.t. Most seedlings were found under heavy canopy cover. On other areas, seedlings were found more commonly under light or moderate cover (Roe 1952) or no cover (Day and Duffy 1963).

Engelmann Spruce and Grand Fir-Both Engelmann spruce and grand fir occurred only in the grand fir habitat types. Engelmann spruce seedlings were predominate under seed-tree cuts in grand fir/mountain maple h.t. and under shelterwoods in grand fir/blue huckleberry h.t. Squillace (1954), working in Montana, suggested that openings of $1,188 \mathrm{ft}(362 \mathrm{~m})$ to $1,320 \mathrm{ft}(402 \mathrm{~m})$ are $\mathrm{max}$ imum size for obtaining good Engelmann spruce regeneration. However, Alexander (1969) in Colorado reported that most seed fell within $198 \mathrm{ft}(60 \mathrm{~m})$ of the seed source even though seed was dispersed as far as $396 \mathrm{ft}$ (121 m) during years of moderate seed production. Ronco (1973) found that most seed fell within $99 \mathrm{ft}(30 \mathrm{~m})$. Alexander and others (1986) recommended that clearcut openings should be no larger than $450 \mathrm{ft}(137 \mathrm{~m})$. Roe (1952) states that clearcutting should only be used on north or east aspects when Engelmann spruce seedlings are desired; shelterwood cuts should be used on south or west aspects. Boyd (1969) found that more seedlings occurred in clearcuts in northern Idaho than in seed-tree cuts or shelterwood cuts.

All seedlings were found on sites with scarification, predominately light scarification. Roe (1952), Boyd and Deitschman (1969), Smith (1954), and Fiedler and others (1985) all reported that most Engelmann spruce seedlings occurred on scarified sites with exposed mineral soil. Day (1964) and Day and Duffy (1963) found that moss and decayed wood were better seedbeds than was mineral soil. In central Idaho, moss mats were very efficient seedbeds in all three habitat types. Most seedlings occurred under heavy shade in grand fir/mountain maple h.t., and under light shade in grand fir/blue huckleberry h.t. Thimbleberry, Sitka alder, and mountain ash (Sorbus scopulina) were very efficient covers in grand fir/mountain maple h.t. Thimbleberry, Engelmann spruce, and Scouler willow (Salix scouleriana) were very efficient or moderately efficient in grand fir/blue huckleberry h.t.

Most grand fir seedlings were found under shelterwoods in grand fir/mountain maple h.t. and in clearcuts in grand fir/blue huckleberry h.t. Boyd (1969) in northern Idaho found more grand fir seedlings in seed-tree cutting units than in clearcuts or shelterwood cuts. Seedling occurrence was highest on scarified sites in both habitat types. Residual duff was a very efficient seedbed in grand fir/mountain maple h.t., and rotten wood was very efficient in grand fir/blue huckleberry h.t. More seedlings occurred in moderate or heavy shade. Mountain maple and russetbuffaloberry (Shepherdia canadensis) were very efficient covers in grand fir/mountain maple h.t., and thimbleberry was very efficient in grand fir/blue huckleberry h.t.

\section{RECOMMENDATIONS}

Following are recommendations for the observed species in the Douglas-fir/white spirea, grand fir/mountain maple, and grand fir/blue huckleberry habitat types in central Idaho.

\section{Douglas-Fir/White Spirea Habitat Type}

Lodgepole Pine-Because lodgepole pine is mostly nonserotinous in central Idaho (Steele and others 1981) care must be taken to maintain the species' residual overstory. Small clearcuts, seed-tree cuts, and shelterwood cuts can be used. All sites should be lightly scarified. Complete removal of competing vegetation is not necessary because lodgepole pine can establish in moderate shade.

Ponderosa Pine-Ponderosa pine is a heavy-seeded species (Minore 1979), so seed-tree cuts and shelterwoods are effective. Light scarification is desired, but seedlings will establish on heavily scarified sites under bitterbrush and big sagebrush. Seedlings will also establish in moderate shade under ceanothus, which often occurs after broadcast burning.

Douglas-fir-Any silvicultural treatment can be used to establish Douglas-fir seedlings. However, clearcuts should be kept small to ensure adequate seed dispersal from the surrounding stand. Broadcast burning or scarification can both be effective. On scarified sites, scattered slash can be used to protect seedlings.

\section{Grand Fir/Mountain Maple Habitat Type}

Lodgepole Pine-The recommendations for lodgepole pine in grand fir/mountain maple h.t. are the same as those for lodgepole pine in the Douglas-fir/white spirea h.t.

Western Larch-Lightly scarified seed-tree cuts are useful to regenerate western larch. Seedlings will establish well under moderate shade of blue huckleberry, currant, and Utah honeysuckle. 
Ponderosa Pine-Small clearcuts or ponderosa pine seed-tree cuts with heavy scarification are effective. Seedlings will establish under moderate shade, particularly under thimbleberry and rose.

Douglas-fir-Small clearcuts, seed-tree cuts, or shelterwoods can be used. Douglas-fir seedlings will establish on residual duff, but regeneration is best on sites with light or heavy scarification. Seedlings will establish under most covers, although regeneration may be low on sites with high coverage of ninebark.

Engelmann Spruce-Shelterwoods or brushy seed-tree cuts that have been lightly scarified should regenerate well. Seedlings will establish under heavy shade, particularly on sites with Sitka alder, thimbleberry, and mountain-ash.

Grand Fir-Scarified shelterwoods are best. Broadcastburned clearcuts that provide moderate shade should also regenerate well.

\section{Grand Fir/Blue Huckleberry Habitat Type}

Lodgepole Pine-Small clearcuts, seed-tree cuts, or shelterwood cuts with good lodgepole pine seed sources around or within the cutting unit are effective. Light scarification is best. Seedlings will establish in moderate shade, particularly on sites with Utah honeysuckle, white spirea, and thimbleberry.

Ponderosa Pine-Good seedling establishment should occur on small, lightly scarified clearcuts or seed-tree cuts with well-placed seed-trees. Seedlings should establish well in moderate shade, especially on sites with thimbleberry.

Douglas-fir-Small clearcuts and seed-tree cuts should produce good results. Both scarification and broadcast burning can be used. Seedlings will regenerate under heavy shade, particularly on sites with thimbieberry and pachistima.

Engelmann Spruce-Lightly scarified shelterwoods can be used to regenerate Engelmann spruce. Seedlings will do well under light cover, particularly under the cover of thimbleberry, blue huckleberry, Scouler willow, and Utah honeysuckle.

Grand Fir-Small scarified or broadcast-burned clearcuts that produce heavy shade cover will regenerate well. Cover of thimbleberry, blue huckleberry, and Scouler willow should provide good cover.

Even though stocking of natural seedlings currently is low in central Idaho, natural regeneration can be used as a viable alternative to planting. While the results of this study are not conclusive, data from this and other investigations should help to determine the best methods to regenerate natural seedlings. With further study and careful application of silvicultural treatments and site preparations, stocking of natural regeneration should increase in time.

\section{REFERENCES}

Alexander, R. R. 1969. Seedfall and establishment of Engelmann spruce in clearcut openings: a case history. Res. Pap. RM-53. Fort Collins, CO: U.S. Department of
Agriculture, Forest Service, Rocky Mountain Forest and Range Experiment Station. 8 p.

Alexander, R. R.; Edminster, C. B.; Watkins, R. K. 1986. Estimating potential Engelmann spruce seed production on the Fraser Experimental Forest, Colorado. Res. Pap. RM-269. Fort Collins, CO: U.S. Department of Agriculture, Forest Service, Rocky Mountain Forest and Range Experiment Station. 7 p.

Barrett, J. S. 1966. A record of ponderosa pine seed flight. Res. Note PNW-38. Portland, OR: U.S. Department of Agriculture, Forest Service, Pacific Northwest Forest and Range Experiment Station. 5 p.

Boe, K. N. 1953. Western larch and Douglas-fir seed dispersal in clearcuttings. Res. Note 129. Missoula, MT: U.S. Department of Agriculture, Forest Service, Northern Rocky Mountain Forest and Range Experiment Station. 3 p.

Boe, K. N. 1956. Regeneration and slash disposal in lodgepole pine clearcuttings. Northwest Science. 30: 1-11.

Boyd, R. J. 1969. Some case histories of natural regeneration in the western white pine type. Res. Pap. INT-63. Ogden, UT: U.S. Department of Agriculture, Forest Service, Intermountain Forest and Range Experiment Station. 24 p.

Boyd, R. J.; Deitschman, G. H. 1969. Site preparation aids natural regeneration in western larch-Engelmann spruce strip clearcuttings. Res. Pap. INT-64. Ogden, UT: U.S. Department of Agriculture, Forest Service, Intermountain Forest and Range Experiment Station. 10 p.

Curtis, J. D.; Foiles, M. W. 1961. Ponderosa pine seed dissemination into group clearcuttings. Journal of Forestry. 59: 766-767.

Dahms, W. G. 1963. Dispersal of lodgepole pine seed into clear-cut patches. Res. Note PNW-3. Portland, OR: U.S. Department of Agriculture, Forest Service, Pacific Northwest Forest and Range Experiment Station. 7 p.

Daniel, T. W.; Helms, J. A.; Baker, F. S. 1979. Principles of silviculture. San Francisco: McGraw-Hill. 500 p.

Day, R. J. 1964. The microenvironments occupied by spruce and fir regeneration in the Rocky Mountains. Department of Forestry Publication 1037. Ottawa, Canada: Department of Forestry, Forest Research Branch. $25 \mathrm{p}$.

Day, R. J.; Duffy, P. J. B. 1963. Regeneration after logging in the Crowsnest Forest. Department of Forestry Publication 1007. Ottawa, Canada: Department of Forestry, Forest Research Branch. $32 \mathrm{p}$.

Fiedler, C. E.; McCaughey, W. W.; Schmidt, W. C. 1985. Natural regeneration in Intermountain spruce-fir forests -a gradual process. Res. Pap. INT-343. Ogden, UT: U.S. Department of Agriculture, Forest Service, Intermountain Forest and Range Experiment Station. $12 \mathrm{p}$.

Foiles, M. W.; Curtis, J. D. 1965. Natural regeneration of ponderosa pine on scarified group cuttings in central Idaho. Journal of Forestry. 63: 530-535.

Gashwiler, J. S. 1970. Plant and mammal changes on a clearcut in west-central Oregon. Ecology. 51: 1018-1026.

Giuntoli, M.; Mewaldt, L. R. 1978. Stomach contents of Clark's nutcrackers collected in western Montana. Auk. 95: 595-598.

Harper, J. L. 1977. Population biology of plants. San Francisco: Academic Press. 892 p. 
Harvey, A. E. 1982. The importance of residual organic debris in site preparation and amelioration for reforestation. In: Baumgartner, D. M., ed. Site preparation and fuels management on steep terrain: symposium proceedings; 1982 February 15-17; Spokane, WA. Pullman, WA: Washington State University, Cooperative Extension: $75-84$

Harvey, A. E.; Jurgensen, M. F.; Larsen, M. J. 1976. Intensive fiber utilization and prescribed fire effects on microbial ecology of plants. Gen. Tech. Rep. INT-28. Ogden, UT: U.S. Department of Agriculture, Forest Service, Intermountain Forest and Range Experiment Station. 46 p.

Hofmann, J. V. 1923. Furred forest planters. The Scientific Monthly. 16: 280-283.

Knapp, A. K.; Smith, W. K. 1982. Factors influencing seedling establishment of Engelmann spruce (Picea engelmannii) and subalpine fir (Abies lasiocarpa) in southeast Wyoming. Canadian Journal of Botany. 60: 2753-2761.

Lanner, R. M. 1980. Avian seed dispersal as a factor in the ecology and evolution of limber and whitebark pines. In: Dancik, Bruce; Higginbotham, Kenneth, eds. Proceedings, 6th North American forest biology workshop; 1980 August 11-13; Edmonton, AB. Edmonton, AB: University of Alberta: 15-48.

Lanner, R. M.; Vander Wall, S. B. 1980. Dispersal of limber pine seed by Clark's nutcracker. Journal of Forestry. 78: 637-639.

McConkie, A.; Mowat, E. L. 1936. A preliminary study of the factors affecting establishment of ponderosa pine and Douglas-fir seedlings in central Idaho. Unpublished preliminary report on file at: U.S. Department of Agriculture, Forest Service, Intermountain Forest and Range Experiment Station, Boise, ID. 66 p.

Minore, D. 1979. Comparative characteristics of northwestern tree species-a literature review. Gen. Tech. Rep. PNW-87. Portland, OR: U.S. Department of Agriculture, Forest Service, Pacific Northwest Forest and Range Experiment Station. 72 p.

Minore, D.; Dubrasich, M. E. 1981. Regeneration after clearcutting in subalpine stands near Windigo Pass, Oregon. Journal of Forestry. 79(9): 619-621.

Mueller-Dombois, D.; Ellenberg, H. 1974. Aims and methods of vegetation ecology. New York: John Wiley and Sons. 547 p.

Roe, A. L. 1952. Larch-Douglas-fir regeneration studies in Montana. Northwest Science. 26(3): 95-102.

Ronco, F. 1973. Food reserves of Engelmann spruce plant ing stock. Forest Science. 19(3): 213-219.

Roy, D. F. 1983. Natural regeneration. In: Rokon, T. E.; Standiford, R. B., eds. Management of the east side pine type in northeastern California. Arcadia, CA: Northern
California Chapter, Society of American Foresters: 87-102.

Saigo, B. W. 1969. The relationship of non-recovered rodent caches to the natural regeneration of ponderosa pine. Corvallis, OR: Oregon State University. 98 p. Thesis.

Shearer, R. C. 1959. Western larch seed dispersal over clearcut blocks in northwestern Montana. Proceedings of the Montana Academy of Sciences. 19: 130-134.

Shearer, R. C.; Schmidt, W. C. 1970. Natural regeneration in ponderosa pine forests of western Montana. Res. Pap. INT-86. Ogden, UT: U.S. Department of Agriculture, Forest Service, Intermountain Forest and Range Experiment Station. 19 p.

Smith, J. H. 1954. A cooperative study of Engelmann spruce-alpine fir silviculture and management. Northwest Science. 28: 157-165.

Squillace, A. E. 1954. Engelmann spruce seed dispersal into a clear-cut area. Res. Note 11. Ogden, UT: U.S. Department of Agriculture, Forest Service, Intermountain Forest and Range Experiment Station. 4 p.

Steele, R. 1986. [Personal communication]. Boise, ID: U.S. Department of Agriculture, Forest Service, Intermountain Research Station, Forestry Sciences Laboratory.

Steele, R.; Geier-Hayes, K. 1985. The grand fir/mountain maple habitat type in central Idaho: succession and management. Boise, ID: U.S. Department of Agriculture, Forest Service, Intermountain Forest and Range Experiment Station, Forestry Sciences Laboratory. 118 p. Preliminary draft.

Steele, R.; Pfister, R. D.; Ryker, R. A.; Kittams, J. A. 1981. Forest habitat types of central Idaho. Gen. Tech. Rep. INT-114. Ogden, UT: U.S. Department of Agriculture, Forest Service, Intermountain Forest and Range Experiment Station. 138 p.

Tackle, D.; Roy, D. F. 1953. Site preparation as related to ground cover density in natural regeneration of ponderosa pine. Tech. Pap. 4. Berkeley, CA: U.S. Department of Agriculture, Forest Service, California Forest and Range Experiment Station. 13 p.

Trappe, J. M. 1959. Lodgepole pine clearcuts in northwestern Oregon. Journal of Forestry. 57: 420-423.

Vander Wall, S. B.; Balda, R. P. 1977. Coadaptions of the Clark's nutcracker and the piñon pine for efficient seed harvest and dispersal. Ecological Monographs. 47: 89-111.

Vander Wall, S. B.; Hutchins, H. E. 1983. Dependence of Clark's nutcracker, Nucifraga columbiana, on conifer seeds during the postfledging period. The Canadian Field-Naturalist. 97: 208-214.

West, N. E. 1968. Rodent-influenced establishment of ponderosa pine and bitterbrush seedlings in central Oregon. Ecology. 49: 1009-1011. 
Geier-Hayes, Kathleen. 1987. Occurrence of conifer seedlings and their microenvironments on disturbed areas in central Idaho. Res. Pap. INT-383. Ogden, UT: U.S. Department of Agriculture, Forest Service, Intermountain Research Station. $12 \mathrm{p}$

Microsite seedbeds and covers were surveyed for six conifer species following various silvicultural-site preparation combinations in three central Idaho habitat types. Seedling occurrence was related to seedbeds, cover, site preparation method, and silvicultural method. An index was developed to indicate potential beneficial or detrimental seedbeds or covers for each species. Recommendations are listed for silvicultural-site preparation practices to obtain desired natural regeneration in the three habitat types.

KEYWORDS: natural regeneration, microsites, central Idaho 


\section{INTERMOUNTAIN RESEARCH STATION}

The Intermountain Research Station provides scientific knowledge and technology to improve management, protection, and use of the forests and rangelands of the Intermountain West. Research is designed to meet the needs of National Forest managers, Federal and State agencies, industry, academic institutions, public and private organizations, and individuals. Results of research are made available through publications, symposia, workshops, training sessions, and personal contacts.

The Intermountain Research Station territory includes Montana, Idaho, Utah, Nevada, and western Wyoming. Eighty-five percent of the lands in the Station area, about 231 million acres, are classified as forest or rangeland. They include grasslands, deserts, shrublands, alpine areas, and forests. They provide fiber for forest industries, minerals and fossil fuels for energy and industrial development, water for domestic and industrial consumption, forage for livestock and wildlife, and recreation opportunities for millions of visitors.

Several Station units conduct research in additional western States, or have missions that are national or international in scope.

Station laboratories are located in:

Boise, Idaho

Bozeman, Montana (in cooperation with Montana State University)

Logan, Utah (in cooperation with Utah State University)

Missoula, Montana (in cooperation with the University of Montana)

Moscow, Idaho (in cooperation with the University of Idaho)

Ogden, Utah

Provo, Utah (in cooperation with Brigham Young University)

Reno, Nevada (in cooperation with the University of Nevada)

USDA policy prohibits discrimination because of race, color, national origin, sex, age, religion, or handicapping condition. Any person who believes he or she has been discriminated against in any USDA-related activity should immediately contact the Secretary of Agriculture, Washington, DC 20250.

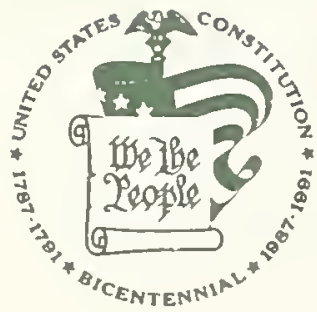

